DR. ROXANA ANDREA VERDINI (Orcid ID : 0000-0002-2339-6904)

Article type : Original Manuscript

\title{
Technological, nutritional and sensorial characteristics of wheat bread fortified with calcium salts
}

Matías G. Rossia,b, Marina Soazo a,b, Gisela N. Piccirillia,b, Emilce E. Llopartc,d, Gilda C. Revelant ${ }^{\mathrm{a}}$, Roxana A. Verdinia, ${ }^{\mathrm{a}}$

a Área Bromatología y Nutrición, Facultad de Ciencias Bioquímicas y Farmacéuticas, Departamento de Ciencias de los Alimentos y del Medio Ambiente (Universidad Nacional de Rosario). Suipacha 531, S2002LRK Rosario, Santa Fe, Argentina.

b Instituto de Química Rosario (Universidad Nacional de Rosario-Consejo Nacional de Investigaciones Científicas y Técnicas), Suipacha 570, S2002LRL Rosario, Argentina.

c Consejo Nacional de Investigaciones Científicas y Técnicas (CONICET), Suipacha 570, S2002LRL Rosario, Argentina.

d Área Alimentos y Sociedad, Facultad de Ciencias Bioquímicas y Farmacéuticas, Departamento de Ciencias de los Alimentos y del Medio Ambiente (Universidad Nacional de Rosario). Suipacha 531, S2002LRK Rosario, Santa Fe, Argentina.

${ }^{*}$ Corresponding author: Roxana A. VERDINI. Tel.: 54-341-4804592 (ext 260); Tel./Fax: 54-341-4372704 ext 137). E-mail address: rverdini@fbioyf.unr.edu.ar, verdini@iquirconicet.gov.ar

Key words: bread, calcium, fortification, bioaccessibility, sensory analysis

Running title: Wheat bread fortified with calcium salts

The peer review history for this article is available at https://publons.com/publon/10.1111/ijfs.14594

This article has been accepted for publication and undergone full peer review but has not been through the copyediting, typesetting, pagination and proofreading process, which may lead to differences between this version and the Version of Record. Please cite this article as doi: $\underline{10.1111 / \text { IJFS.14594 }}$

This article is protected by copyright. All rights reserved 


\section{Abstract}

The aim of this paper was to carry out a comprehensive study of wheat flour breads fortified with different sources of calcium, which includes: technological, nutritional and sensorial characteristics. Calcium salts (lactate: LA, carbonate: CA, and citrate: $\mathrm{Cl}$ ) at two fortification levels (20 and 50\%) were analysed. Only the LA fortified breads were harder with lower specific volume and the LA $50 \%$ showed the higher chewiness value. The crust colour of the $\mathrm{Cl} 50 \%$ breads presented the lower browning index. In vitro nutritional studies showed that calcium content on digest and dialysate was significantly higher in all fortified breads. The CA $20 \%$ and all the $50 \%$ fortifications showed a better contribution of bioaccessible calcium. Sensorial general quality was not significantly different between fortified and Control breads. 


\section{Introduction}

Calcium is an essential nutrient that is necessary for many functions in human health and is the most abundant mineral in the body, being $99 \%$ found in teeth and bone and only $1 \%$ in serum (Beto, 2015). Normal growth and development of skeleton and teeth are associated with an appropriate calcium intake. Risk for osteoporosis and bone fractures in adulthood has been detected when calcium intake is low (Bailey et al., 2010).

Recommended dietary allowance (RDA) for calcium is different according to age, gender and local regulations. The USDA (US Department of Agriculture) and the Argentinean Alimentarius Codex (AAC, 2013) recommend a RDA of 1300 mg/day and 1000 mg/day, respectively. Data from Europe, the USA and Argentina allowed concluding that a large percentage of the population does not meet the requirements currently recommended for optimal calcium intake due to cultural or economic factors (NN\&HS, 2007; Kaganov et al., 2015). Bailey et al. (2010) evaluated calcium intake in the USA finding that in the older age groups the prevalence of meeting the RDA increased because high percentage of the population in the USA takes calcium supplements. However, it is recommended to achieve the optimal intake of calcium through dietary sources and not through supplements. Therefore, it is necessary to search for alternatives in order to correct the deficiency in calcium intake, being food fortification an interesting option. The UK, for instance, decided to fortify wheat flour with calcium carbonate contributing in this way to approximately $14 \%$ of total calcium intake (cited by Krupa-Kozak et al., 2012).

When fortifying food it is necessary to estimate the efficiency of the process by determining the bioavailability of the added nutrient (Rebellato et al., 2017). Dialysability is an in vitro test that simulates gastrointestinal digestion (Wolfgor et al., 2002). This method can be used as an alternative to human or animal studies in regards to bioavailability estimation, since significant correlation with in vivo methods has been reported (Miller et al., 1981). Furthermore, using dialysability and total calcium content of the food, potential calcium contribution can be determined (Zuleta et al., 2012).

Bread is one of the most consumed staple foods; consequently, it has been selected by some authors as a product to be fortified with calcium. Ranhotra et al. (1997) studied the relative bioavailability in vivo of calcium in breads fortified with different calcium sources, including inorganic (carbonate and sulfate), organic (citrate and lactate) and a brandname calcium supplement. They concluded that calcium was equally well available 
from all sources. Salinas and Puppo (2015) analysed the impact of calcium carbonate combined with the prebiotic inulin on wheat bread properties, showing that the prebiotic negatively affected breadmaking quality. Moreover different researches evaluated the effect of several sources of calcium on dough rheological properties (Salinas and Puppo, 2014; Sehn et al. 2015; Tuhumury et al. 2016; Codinăa et al. 2018). Although the incorporation of calcium could affect the taste and the quality of bread, only a few authors carried out sensory analyses (Ziadeh et al., 2005, Krupa-Kozak et al., 2011).

The aim of the present work was to prepare breads with different calcium salts (inorganic and organic calcium sources) at two levels of calcium and carry out a complete study including technological, sensory and nutritional characteristics of bread.

\section{Materials and methods}

\subsection{Ingredients and chemicals}

Wheat flour type 000 (classified according to the AAC) was obtained from Favorita (Ciudad Autónoma de Buenos Aires, Argentina). Baker's yeast and salt were purchased from a local supermarket. Calcium carbonate $(\mathrm{CA})$, calcium citrate $(\mathrm{Cl})$, and calcium lactate (LA) were purchased from Novalquim SRL (Rosario, Argentina). Enzymes: $\alpha-$ amylase (A-3176, from porcine pancreas), pepsin ( $\mathrm{P}-7000$, from porcine gastric mucosa), pancreatin ( $\mathrm{P}-1750$, from porcine pancreas), and bile (B-8631, porcine extract) were obtained from Sigma Chemical Co. (MO, USA). Chlorhydric acid, nitric acid, and sodium bicarbonate were analytical grade.

\subsection{Flour chemical analysis}

Chemical characterization of wheat flour was performed in order to determine moisture, protein, and ash contents, which were determined according to the AOAC methods 925.10; 979.09 and 923.03 respectively (AOAC, 1998).

\subsection{Breadmaking}

The average bread intake in Argentina is $200 \mathrm{~g}$ and the AAC defines mineral fortified foods as those in which the mineral content is between $20 \%$ and $50 \%$ of the RDA. Consequently, flour fortification was made in two theoretical levels corresponding to $20 \%$ and $50 \%$ of the calcium RDA. Control and fortified breads were obtained using the 
ingredients listed on Table 1. Ingredients were placed into an automatic bread maker (ATMA HP4060E, China), mixed, kneaded for $20 \mathrm{~min}$ and fermented for $40 \mathrm{~min}$ at $35^{\circ} \mathrm{C}$ (first proof). After that, dough was divided into $200 \mathrm{~g}$ pieces, hand-rounded, and let to rest for $15 \mathrm{~min}$. Then, rounded pieces were sheeted and curled to form a "swiss roll" effect. A second proof, controlled with a push-meter used to measure the proofing (Aguirre et al., 2011), was carried out at $27^{\circ} \mathrm{C}$ and $80 \%$ relative humidity until dough pieces doubled their volume, after which they were baked at $180^{\circ} \mathrm{C}$ for $26 \mathrm{~min}$ in a pre-heated oven (Brafh HC 4.70, Rosario, Argentina). Finally, loaves were cooled at room temperature. Three loaves were obtained for each formula, which were considered as replications for the following determinations.

\subsection{Moisture content, weight, volume and specific volume}

Moisture content was determined according to the air-oven method AACC 44-15A (AACC, 2000). Loaf weight was determined with a Boeco BAS 31PLUS balance (Germany). Loaf volume was measured according to the rapeseed displacement method AACC 10-05 (AACC, 1983). Specific volume $(\mathrm{mL} / \mathrm{g})$ was calculated by dividing the bread volume by its weight.

\subsection{Crumb texture analysis}

Textural profile analysis (TPA) of the bread crumb was performed using a motorized test frame Mecmesin Multitest 2.5d (Sterling, VA, USA) equipped with a $100 \mathrm{~N}$ digital force gauge. Cylindrical shape crumb slices (36 mm diameter and $25 \mathrm{~mm}$ height) were cut from the middle part of the loaf and tested. Samples were compressed twice with no delay between them, to $40 \%$ of its original height with the $100 \mathrm{~mm}$ diameter cylindrical probe at a crosshead speed of $300 \mathrm{~mm} / \mathrm{min}$ (Licciardello et al., 2014). Parameters obtained were: hardness (force determined on the first peak), cohesiveness (ratio between second and first compression peaks), springiness (distance between the start of the second cycle and its peak) and chewiness (hardness $\times$ cohesiveness $\times$ springiness).

\subsection{Digital image analysis}

A wooden box according to the design described by Soazo et al. (2015) was used. Samples were photographed employing a Canon Eos Rebel T3 digital camera (China) on 
a matte black background. Camera was set in manual mode with lens aperture at $f=8$, time of exposition $1 / 200$, no flash, ISO sensibility 400 , maximum resolution. Images were stored in RAW format. A Wolf Faust IT8 calibration card (Frankfurt, Germany) was photographed with setting described and used to obtain the International Color Consortium (ICC) profile employing the LProf software (Marti, 2005).

\subsubsection{Crust colour analysis}

Entire loaves were used to obtain the digital images. Colour was determined in the CIELab colour space. In order to obtain $L^{*}$ (lightness component), $a^{*}$ (green to red component), and $b^{*}$ (blue to yellow component) parameters, images were processed using Photoshop ${ }^{\circledR}$ (Adobe Systems Inc., CA, USA) acquiring average values. Browning Index (BI) was calculated using the following equation (Correa et al., 2017):

$$
\mathrm{BI}=\frac{100 \times(\mathrm{X}-0,31)}{0,172}
$$

Where:

$$
X=\frac{\left(a^{*}+1,75 \times L^{*}\right)}{\left(5,645 \times L^{*}+a^{*}-3,012 \times b^{*}\right)}
$$

\subsubsection{Crumb grain diameter}

Crumb slices cut from the middle part of the each loaf were used to obtain the digital images. Images were processed using ImageJ together with BoneJ, a bone measurement ImageJ plugin that allowed us to measure the local thickness of the grains in the 2D images (Rasband, 2015; Doube et al., 2010). First, images were subjected to a binarization with ImageJ where the foreground, the crumb matrix, was converted into black, and the background, the grains, into white. The thickness at a point can be defined as the diameter of the greatest sphere that fits within a structure and contains the point. Diameters and their absolute frequencies were obtained and relative frequencies were calculated. Finally, the diameters were grouped in three intervals ranging from $0-0.10$, $0.11-0.20$ and $0.21-0.30 \mathrm{~cm}$ (small, medium and large holes, respectively). 


\subsection{Dialysability assay}

Calcium dialysability assay was performed as described by Drago et al. (2005) with some modifications. Samples were grounded and $11.5 \mathrm{~g}$ of this powder was homogenized with $38.5 \mathrm{~mL}$ of distilled water. A first digestion was carried out by adding $5.0 \mathrm{~mL}$ of $4.0 \mathrm{~g}$ of aamylase in $60 \mathrm{~mL}$ of distilled water. The mixture was incubated in a shaking water bath at $37^{\circ} \mathrm{C}$ for $2 \mathrm{~h}$. Once the incubation was finished, $\mathrm{pH}$ was adjusted to 2.0 using $6 \mathrm{M} \mathrm{HCl}$ to perform the pepsin digestion by the addition of $1.6 \mathrm{~mL}$ of: $16.0 \mathrm{~g}$ of pepsin in $100 \mathrm{~mL}$ of $0.1 \mathrm{M} \mathrm{HCl}$, shaking incubation at $37^{\circ} \mathrm{C}$ was resumed for another $2 \mathrm{~h}$ and the solution constituted the digest. Afterwards, a $3-5 \mathrm{~g}$ aliquot of the digest was wet ashed by heating with $10 \mathrm{~mL}$ of $\mathrm{HNO}_{3}$ to determine calcium by atomic absorption spectroscopy. A UNICAM SOLAAR 969 (Unicam Ltd., Cambridge, United Kingdom) spectrophotometer was used. A third stage was conducted adding a $15-16 \mathrm{~g}$ aliquot of the digest on a 100 $\mathrm{mL}$ beaker, in which a dialysis bag was incorporated. Spectra/Por dialysis tubing, diameter $14.6 \mathrm{~mm}$, length $20.0 \mathrm{~mm}, 6000$ - 8000 molecular cut off (Spectrum, USA) containing $18.75 \mathrm{~mL}$ of PIPES buffer (5.2 g of PIPES disodium salt in $100 \mathrm{~mL}$ of distilled water, $\mathrm{pH}$ adjusted to $6.6-6.9$ with $6 \mathrm{M} \mathrm{HCl}$ ) were used. The beakers, with the pepsin digest aliquot and the dialysis bag, were taken to the shaking water bath $\left(37^{\circ} \mathrm{C}\right.$, until pH was approximately 5.0). Afterwards, $3.75 \mathrm{~mL}$ of pancreatin-bile suspension ( $0.4 \mathrm{~g}$ of pancreatin and $2.5 \mathrm{~g}$ of bile in $100 \mathrm{~mL}$ of $0.1 \mathrm{M} \mathrm{NaHCO}_{3}$ ) were added on the beaker and digestion continued for $2 \mathrm{~h}$. Finally, the dialysis bag was removed from the beaker, rinsed with distilled water and its content was transferred to a flask and weighed, constituting the dialysate. The dialysate was also wet ashed to determine calcium content. Also total calcium content on whole bread was determined by atomic absorption spectrophotometry according to the AACC 40-70 method (AACC, 2000).

Potential calcium contribution ( $\mathrm{PCaC}$ ) was calculated with the following equation:

$$
\mathrm{PCaC}=\frac{\text { total calcium content }(\mathrm{mg} \text { of } \mathrm{Ca} / \text { portion of } 200 \mathrm{~g}) \times \mathrm{DCa} \%}{100}
$$

Where:

$$
\mathrm{DCa} \%=\frac{\text { calcium content on dialysate }(\mathrm{mg} \text { of } \mathrm{Ca} / \mathrm{g} \text { of dialysate }) \times 100}{\text { calcium content on digest }(\mathrm{mg} \text { of } \mathrm{Ca} / \mathrm{g} \text { of digest })}
$$




\subsection{Sensory analysis}

Sensory evaluation of loaves was carried out for various attributes namely foreign aroma, crust colour, crumb colour, foreign taste, hardness, chewiness, alveoli and general quality, according to the quantitative descriptive analysis methodology (QDA) proposed by Stone et al. (2012). A trained panel of eight members evaluated the samples for all the previously mentioned attributes, using scale of $10 \mathrm{~cm}$ nonstructured scale anchored at the extremes 1 by 'none/weak' and 9 'very strong'. Panelists were seated in a room free of noise and odours and suitably illuminated. Three slices of bread including crumb and crust were presented in white disposable plates with three-digit numbers randomly coded. Water was provided for palate cleansing.

\subsection{Statistical analysis}

All the analyses were carried out in triplicate. Statistical analysis was performed using Statgraphics Plus 5.1 (Statpoint Technologies, Inc., VA, USA). Analysis of variance was used and when the effect of the factors was significant $(p<0.05)$, the test of multiple ranks honestly significant difference (HSD) of Tukey was applied (95\% of confidence level).

\section{Results and discussion}

\subsection{Flour composition}

Average values obtained in our laboratory: $12.9 \pm 0.3 \%$ moisture, $12.1 \pm 0.2 \%$ protein, and $0.65 \pm 0.01 \%$ ash content. These results are in accordance with the AAC in regards to the wheat flour type 000 classification.

\subsection{Moisture content}

Moisture content of breads is shown in Table 2. No significant difference was observed when comparing Control and fortified breads. The amount of water used during bread making was constant for all the formulations, explaining the obtained moisture values. 


\subsection{Weight, volume and specific volume}

Results of weight, volume and specific volume tests are shown in Table 2. Bread weight was not affected by the addition of the salts when comparing with Control breads. However, a significant decrease was observed in bread volume for the LA 50\% fortification and in specific volume for both levels when fortification was made with LA. Salinas and Puppo (2014) reported a destabilization of the gluten network generated by the addition of LA into dough. Thus, this effect could be the cause of the decrease in bread specific volume observed for LA fortifications. However, Krupa-Kozak et al. (2012) studied the effect of calcium salts on gluten-free breads and observed that, when comparing LA, CA and $\mathrm{Cl}$ with control breads, only LA reduced specific volume. Consequently, LA not only destabilized the gluten network but an additional effect may be involved. Pattison and von Holy (2001) studied the effect of selected compounds on baker's yeast (Saccharomyces cerevisiae) activity observing that LA reduced this activity up to $37.4 \%$ compared with a control. Furthermore, these authors detected that an increase in LA concentration conducted to a yeast activity reduction. One of the most important functions of baker's yeast in bread making is the production of $\mathrm{CO}_{2}$ during proof due to the alcoholic fermentation of sugars. Gas produced during this stage will cause an increase in dough and bread volume. As a consequence of the addition of LA to dough, yeast activity could have been reduced and $\mathrm{CO}_{2}$ production decreased leading to loaves with significantly lower specific volume as observed in LA fortifications compared with Control.

\subsection{Crumb texture analysis}

Table 3 shows the parameters obtained from the TPA of breads. Cohesiveness and springiness were not affected by the addition of calcium salts. However, hardness significantly increased compared to Control when LA was used. Hardness is related with the sensory of lack of freshness in bakery products (Young, 2012), so the increase in this parameter might cause the consumer to reject the product due to the perception of stale bread. A negative correlation between loaf specific volume and crumb hardness was reported (Salinas and Puppo, 2014). This effect can be explained by the fact that highvolume bread will contain a larger volume of air cells which do not contribute to hardness (van Eijk and Hille, 1996). Considering that breads fortified with LA showed lower specific 
volume than Controls, then it was expected to observe higher values for hardness. In addition, chewiness, parameter directly related to hardness, was significantly higher for LA $50 \%$.

\subsection{Digital image analysis}

\subsubsection{Crust colour analysis}

Digital images of breads are shown in Figure 1. Results of colour analysis are shown in Table 4. Fortification with CA at both levels has not affected any of the crust colour parameters when comparing to Control breads. However, fortification with LA and $\mathrm{Cl}$ affected at least one of the colour parameters when calcium level was $50 \%$. Furthermore, breads fortified with $\mathrm{Cl} 50 \%$ showed a significantly lower $\mathrm{BI}$ than Control breads which means that $\mathrm{Cl} 50 \%$ yielded paler breads. In agreement, Bell et al. (1998), when analyzing the effect of salt (phosphate and citrate) type in low moisture systems, observed that browning rate constants were lower in the presence of citrate than those for phosphate at the same buffer concentration. However, as salt content in the solid increased, the authors observed that the browning rate constant increased for phosphate but decreased for citrate. The authors related their observations with the fact that phosphate buffer has been reported to catalyze nonenzymatic browning in solutions and citrate is a much weaker catalyst, especially for the Maillard reaction, where no catalytic effect was reported.

\subsubsection{Crumb grain diameter}

The relative frequencies of the diameters of the holes grouped in the three intervals are shown in Table 4. The distribution of the holes showed a high frequency of small holes (average 85\%), followed medium holes (average 13\%), and big holes (average 2\%). Most of the baked products have a characteristic crumb formed of holes of different shapes, sizes and distributions (Cauvain, 2007). No significant differences were observed between Control and fortified breads.

\subsection{Calcium dialysability and potential calcium contribution}

Calcium content of digest and dialysate and PCaC are shown in Table 5. Calcium content of the digest of samples was nearly theoretical values (200 and $500 \mathrm{mg}$ of 
$\mathrm{Ca} /$ portion of $200 \mathrm{~g}$ of bread). The presence of calcium on Control breads can be attributed to the occurrence of the mineral in some ingredients i.e.: wheat flour, tap water, etc. In regards to calcium content on the dialysate, it was significantly higher for all of the fortifications in comparison to Control breads. Besides, $50 \%$ fortifications showed, as expected, significantly higher calcium contents than $20 \%$ fortifications. The PCaC, that represents the bioaccesible calcium in relation to the added calcium, is the best parameter to analyse different salts and fortification levels tested. The PCaC was significantly higher for $\mathrm{Cl} 20 \%$, when compared to Controls, while only an increasing trend was observed for the remaining $20 \%$ fortifications. All fortifications made at $50 \%$ showed a PCaC significantly higher than Controls, being both $\mathrm{LA}$ and $\mathrm{Cl}$ higher than $\mathrm{CA}$. This may be related to the lower solubility of CA. Some authors elaborated breads using mixtures of wheat flour and non-traditional flours rich in calcium like amaranth flour (Dyner et al., 2007) or American carob flour (Zuleta et al., 2012). The PCaC determined for our fortifications (average PCaC for $20 \%$ fortifications: $77.7 \mathrm{mg} / 100 \mathrm{~g}$ of bread, and average $\mathrm{PCaC}$ for $50 \%$ fortifications: $169.3 \mathrm{mg} / 100 \mathrm{~g}$ of bread) were higher than those reported for amaranth flour (PCaC: $8.07 \mathrm{mg} / 100 \mathrm{~g}$ of bread) and American carob flour (PCaC: $20.8 \mathrm{mg} / 100 \mathrm{~g}$ of bread). Thus, salts and fortification levels tested resulted to provide a good contribution of bioaccesible calcium thanks to high $\mathrm{PCaC}$ values.

\subsection{Sensory analysis}

The spider web for QDA sensory analysis of breads is shown in Figure 2. The incorporation of calcium salts did not significantly affect the foreign aroma, crumb colour, hardness, chewiness and alveoli of breads. In agreement, previous research of Romanchik-Cerpovicz and McKemie (2007) had shown that CA, Cl and LA did not affect sensory characteristics of wheat-flour tortillas fortified with calcium at level of $10 \%$ of the adequate intake for adults. A foreign taste described as bitter was detected in the LA $50 \%$ breads. Krupa-Kozak et al. (2012), investigated fortification of gluten-free bread containing inulin with different calcium sources (CA, Cl, LA and calcium chloride). The authors reported that breads with LA showed the lowest sensory scores as a consequence of their poor taste, which was described as bitter. The aforementioned results confirm the importance of determining the salt thresholds below which their incorporation is not detectable. Ziadeh et al. (2005) prepared pita bread loaves from 
flours fortified with, CA and $\mathrm{Cl}$, and reported detection thresholds of 1994 and 2132 (mg/100 g bread) for $\mathrm{CA}$ and $\mathrm{Cl}$, respectively. Breads formulated in the present investigation with $\mathrm{CA}$ and $\mathrm{Cl}$ had a fortification level below those thresholds. It is important to remark that the results obtained for LA breads could constitute an estimation of the threshold value perceived for panellist for this calcium salt. In reference to colour parameters, all salts studied in the present investigation are either white or colourless, however the colour of the $\mathrm{Cl} 50 \%$ crust received a lower score in agreement with a lower $L^{*}, a^{*}, b^{*}$ and $\mathrm{BI}$ parameters measured in the $\mathrm{Cl} 50 \%$ breads. In spite of the minor differences previously mentioned, the general quality parameter was not significantly different between fortified and Control breads.

\section{Conclusion}

This study demonstrated that fortification of wheat flour bread with calcium salts is an effective approach to provide population with an important source of bioaccesible calcium. However, the impact of some calcium salts on the properties of breads must be taken in consideration. The effect of LA fortifications on hardness and chewiness of the breads could be a consequence of the effect of LA on the reduction of yeast activity and destabilization of gluten network. On the other hand, no major changes were observed for $\mathrm{Cl}$ and $\mathrm{CA}$ in regards to bread physicochemical properties respect to the Control breads, though the $\mathrm{Cl} 50 \%$ ones resulted to be paler. However, paler colour could be solved by a slight increase on baking time. Since all breads elaborated resulted to show high values of $\mathrm{PCaC}$ the fortification with the studied calcium salts can be recommended. Moreover, higher fortification levels can be tested to improve PCaC and also the addition of an enhancer of calcium absorption can be investigated. For a successful fortification, fortified foods should have similar sensory characteristics as their nonfortified counterparts. This requirement is particularly important for calcium fortification in which, compared with other micronutrients, this mineral will have to be added in larger amounts. Sensorial general quality was not significantly different between fortified and Control breads. This may be a promising result considering perspective consumer acceptability of breads. 


\section{Acknowledgements}

This study was conducted with the financial support of Secretaria de Ciencia, Tecnología e Innovación de la Provincia de Santa Fe (SECTel, Argentina), Consejo Nacional de Investigaciones Científicas y Técnicas (CONICET, Argentina), and Agencia Nacional de Promoción Científica y Tecnológica (ANPCyT, Argentina). We acknowledge Prof. María Lujan Medina Ineichen for English revision.

\section{Ethics approval}

Ethics approval was not required for this research.

\section{Ethics approval}

The paper has no conflict of interest.

\section{Data Availability Statement}

Research data are not shared.

\section{References}

AAC. (2018). Argentinean Alimentarius Codex. (Chapter XVII Art 1363). Retrieved from https://www.argentina.gob.ar/sites/default/files/anmatcapitulo_xvii_dieteticosactualiz_2018-12.pdf

AACC. (1983). Approved methods of the American Association of Cereal Chemists (8th ed.). St. Paul, Mn: AACC International.

AACC (2000). Approved methods of the American Association of Cereal Chemists (10th ed.). St. Paul, Mn: AACC International. 
Aguirre, J. F., Osella, C. A., Carrara, C. R., Sánchez, H. D., \& Buera, M. d. P. (2011). Effect of storage temperature on starch retrogradation of bread staling. Starch Stärke, 63, 587-593.

AOAC. (1998). Official Methods of Analysis of AOAC International. Gaithersburg, MD: AOAC International.

Bailey, R. L., Dodd, K. W., Goldman, J. A., Gahche, J. J., Dwyer, J. T., Moshfegh, A. J., Sempos, C. T. \& Picciano, M. F. (2010). Estimation of total usual calcium and vitamin D intakes in the United States. Journal of Nutrition, 140, 817-822.

Bell, L. N., White, K. L., \& Chen, Y. H. (1998). Maillard Reaction in Glassy Low-Moisture Solids as Affected by Buffer Type and Concentration. Journal of Food Science, 63, 785-788.

Beto, J. A. (2015). The role of calcium in human aging. Clinical Nutrition Research, 4(1), $1-8$.

Cauvain, S. P. (2007). Bread-the Product. In: Technology of Breadmaking (edited by S. P. Cauvain \& L. S. Young). Pp. 1-19. $2^{\text {nd }}$ ed. New York, USA: Springer.

Codină, G. G.,Zaharia, D., Stroe, S-G. and Ropciuca, S. (2018). Influence of calcium ions addition from gluconate and lactate salts on refined wheat flour dough rheological properties. Cyta-Journal of Food, 16, 884-891.

Correa, M. J., V. Salinas, M., Carbas, B., Ferrero, C., Brites, C., \& Puppo, M. (2017). Technological quality of dough and breads from commercial algarroba-wheat flour blends. Journal of Food Science and Technology, 54, 2104-2114.

Doube, M., Kłosowski, M. M., Arganda-Carreras, I., Cordelières, F. P., Dougherty, R. P., Jackson, J. S., Schmid, B., Hutchinson, J. R. \& Shefelbine, S. J. (2010). BoneJ: free and extensible bone image analysis in ImageJ. Bone, 47, 1076-1079.

Drago, S. R., Binaghi, M., \& Valencia, M. E. (2005). Effect of Gastric Digestion pH on Iron, Zinc, and Calcium Dialyzability from Preterm and Term Starting Infant Formulas. Journal of Food Science, 70, S107-S112.

Dyner, L., Drago, S. R., Piñeiro, A., Sánchez, H., González, R., Villaamil, E., \& Valencia, M. E. (2007). Composición y aporte potencial de hierro, calcio y zinc de panes y 
fideos elaborados con harinas de trigo y amaranto. Archivos Latinoamericanos de Nutrición, 57, 69-78.

Kaganov, B., Caroli, M., Mazur, A., Singhal, A., \& Vania, A. (2015). Suboptimal Micronutrient Intake among Children in Europe. Nutrients, 7, 3524-3535.

Krupa-Kozak, U., Troszyńska, A., Bączek, N., \& Soral-Śmietana, M. (2011). Effect of organic calcium supplements on the technological characteristic and sensory properties of gluten-free bread. European food research and technology, 232(3), 497-508.

Krupa-Kozak, U., Altamirano-Fortoul, R., Wronkowska, M., \& Rosell, C. M. (2012). Breadmaking performance and technological characteristic of gluten-free bread with inulin supplemented with calcium salts. European Food Research and Technology, 235, 545-554.

Licciardello, F., Cipri, L., \& Muratore, G. (2014). Influence of packaging on the quality maintenance of industrial bread by comparative shelf life testing. Food Packaging and Shelf Life, 1, 19-24.

Marti, M. (2005). LProf (Version 1.11). Retrieved from http://sourceforge.net/projects/lprof/files/latest/download?source=files

Miller, D. D., Schricker, B. R., Rasmussen, R. R., \& Van Campen, D. (1981). An in vitro method for estimation of iron availability from meals. The American Journal of Clinical Nutrition, 34, 2248-2256.

NN\&HS. (2007). National Nutrition and Health Survey. Buenos Aires, Argentina: Ministerio de Salud. Retrieved from: http://www.msal.gob.ar/images/stories/bes/graficos/0000000257cnt-a08-ennysdocumento-de-resultados-2007.pdf

Pattison, T. L., \& von Holy, A. (2001). Effect of selected natural antimicrobials on Baker's yeast activity. Letters in Applied Microbiology, 33, 211-215.

Ranhotra, G. S., Gelroth, J. A., Leinen, S. D., \& Schneller, F. E. (1997). Bioavailability of Calcium in Breads Fortified with Different Calcium Sources. Cereal Chemistry, 74, 361-363. 
Rasband, W. S. (2015). National Institutes of Health, Bethesda, Maryland, United States. Retrieved from: http://imagej.nih.gov/ij/

Rebellato, A. P., Bussi, J., Silva, J. G. S., Greiner, R., Steel, C. J., \& Pallone, J. A. L. (2017). Effect of different iron compounds on rheological and technological parameters as well as bioaccessibility of minerals in whole wheat bread. Food Research International, 94, 65-71.

Romanchik-Cerpovicz, J. E., \& McKemie, R. J. (2007). Fortification of all-purpose wheatflour tortillas with calcium lactate, calcium carbonate, or calcium citrate is acceptable. Journal of the American Dietetic Association, 506-509.

Salinas, M. V., \& Puppo, M. C. (2014). Rheological Properties of Bread Dough Formulated with Wheat Flour-Organic Calcium Salts-FOS-Enriched Inulin Systems. Food and Bioprocess Technology, 7, 1618-1628.

Salinas, M. V., \& Puppo, M. C. (2015). Optimization of the formulation of nutritional breads based on calcium carbonate and inulin. LWT - Food Science and Technology, 60, 95-101.

Sehn, G. A. R., Nogueira, A. C., Almeida, E. L., Chang, Y. K., \& Steel, C. J. (2015). Fortification of wheat dough with calcium and magnesium ions affects empirical rheological properties. Cereal Chemistry, 92, 405-410.

Soazo, M., Pérez, L. M., Rubiolo, A. C., \& Verdini, R. A. (2015). Prefreezing application of whey protein-based edible coating to maintain quality attributes of strawberries. International Journal of Food Science \& Technology, 50, 605-611.

Stone, H., Bleibaum, R. N., \& Thomas, H. A. (2012). Descriptive Analysis. In: Sensory Evaluation Practices. Pp. 233-289. $4^{\text {th }}$ ed. London, UK: Elsevier.

Tuhumury, H. C. D., Small, D. M., \& Day, L. (2016). Effects of hofmeister salt series on gluten network formation: Part I. Cation series. Food Chemistry, 212, 789-797.

van Eijk, J. H., \& Hille, J. D. R. (1996). Nonamylolytic enzymes. In: Baked goods freshness: technology, evaluation, and inhibition of staling (edited by R. E. Hebeda \& H. F. Zobel). Pp. 131-150. New York, USA: Marcel Dekker, Inc. 
Wolfgor, R., Drago, S. R., Rodriguez, V., Pellegrino, N. R., \& Valencia, M. E. (2002). In vitro measurement of available iron in fortified foods. Food Research International, 35, 85-90.

Young, L. S. (2012). Applications of texture analysis to dough and bread. In: Breadmaking (edited by S. P. Cauvain). Pp. 562-579. $2^{\text {nd }}$ ed. Cambridge: Woodhead Publishing.

Ziadeh, G., Shadarevian, S., Malek, A., Khalil, J., Haddad, T., Haddad, J., \& Toufeili, I. (2005). Determination of sensory thresholds of selected calcium salts and formulation of calcium-fortified pocket-type flat bread. Journal of Food Science, 70(8), 548-552.

Zuleta, Á., Binaghi, M. J., Greco, C. B., Aguirre, C., De la Casa, L., Tadini, C., \& Ronayne de Ferrer, P. A. (2012). Diseño de panes funcionales a base de harinas no tradicionales. Revista chilena de nutrición, 39, 58-64.

\section{ANNOTATED REFERENCES}

1. Krupa-Kozak, U., Altamirano-Fortoul, R., Wronkowska, M., \& Rosell, C. M. (2012). Breadmaking performance and technological characteristic of gluten-free bread with inulin supplemented with calcium salts. European Food Research and Technology, 235, 545-554.

Annotations: This paper was cited because the authors studied the effect of calcium lactate, citrate and carbonate in gluten-free breads. The paper was very useful to compare and discuss our results. Particularly, in physicochemical analysis and sensory analysis.

2. Salinas, M. V., \& Puppo, M. C. (2014). Rheological Properties of Bread Dough Formulated with Wheat Flour-Organic Calcium Salts-FOS-Enriched Inulin Systems. Food and Bioprocess Technology, 7, 1618-1628.

Annotations: This paper was cited because the authors studied the effect of calcium lactate and citrate and carbonate in wheat flour breads. The paper was very useful to compare and discuss our results. Particularly, to discuss the correlation between specific volume and crumb texture. 
3. Ziadeh, G., Shadarevian, S., Malek, A., Khalil, J., Haddad, T., Haddad, J., \& Toufeili, I. (2005). Determination of sensory thresholds of selected calcium salts and formulation of calcium-fortified pocket-type flat bread. Journal of Food Science, 70(8), 548-552.

Annotations: This paper was cited because the authors studied bread loaves from flours fortified with calcium carbonate and citrate. They analysed and reported detection thresholds for those salts and were useful for the discussion of sensory analysis results.

4. Zuleta, Á., Binaghi, M. J., Greco, C. B., Aguirre, C., De la Casa, L., Tadini, C., \& Ronayne de Ferrer, P. A. (2012). Diseño de panes funcionales a base de harinas no tradicionales. Revista chilena de nutrición, 39, 58-64.

Annotations: This paper was cited because the authors discussed the potential calcium contribution. This parameter represents the bioaccesible calcium in relation to the added calcium and is the best parameter to analyse different salts and fortification levels tested. 
Table 1. Ingredients employed for breadmaking.

\begin{tabular}{c|ccccc}
\hline Fortification & $\begin{array}{c}\text { Flour } \\
(\mathbf{g})\end{array}$ & $\begin{array}{c}\text { Salt } \\
(\mathbf{g})\end{array}$ & $\begin{array}{c}\text { Yeast } \\
(\mathbf{g})\end{array}$ & $\begin{array}{c}\text { Water } \\
(\mathbf{m L})\end{array}$ & $\begin{array}{c}\text { Calcium salt } \\
(\mathbf{g})\end{array}$ \\
\hline Control & 450.0 & 9.0 & 9.0 & 240 & 0.0 \\
LA 20\% & 446.1 & 9.0 & 9.0 & 240 & 3.9 \\
LA 50\% & 440.3 & 9.0 & 9.0 & 240 & 9.7 \\
CA 20\% & 448.7 & 9.0 & 9.0 & 240 & 1.3 \\
CA 50\% & 446.8 & 9.0 & 9.0 & 240 & 3.2 \\
CI 20\% & 447.6 & 9.0 & 9.0 & 240 & 2.4 \\
CI 50\% & 444.0 & 9.0 & 9.0 & 240 & 6.0 \\
\hline
\end{tabular}


Table 2. Moisture content, weight, volume and specific volume of breads.

\begin{tabular}{c|cccc}
\hline Fortification & $\begin{array}{c}\text { Moisture } \\
\text { content } \\
(\%)\end{array}$ & $\begin{array}{c}\text { Weight } \\
(\mathbf{g})\end{array}$ & $\begin{array}{c}\text { Volume } \\
(\mathbf{m L})\end{array}$ & $\begin{array}{c}\text { Specific volume } \\
(\mathbf{m L} / \mathbf{g})\end{array}$ \\
\hline Control & $29 \pm 1^{\mathrm{a}}$ & $171 \pm 1^{\mathrm{ab}}$ & $497 \pm 39^{\mathrm{b}}$ & $2.9 \pm 0.2^{\mathrm{b}}$ \\
LA 20\% & $28.8 \pm 0.5^{\mathrm{a}}$ & $172 \pm 1^{\mathrm{b}}$ & $468 \pm 12^{\mathrm{ab}}$ & $2.73 \pm 0.08^{\mathrm{a}}$ \\
LA 50\% & $29.4 \pm 0.5^{\mathrm{a}}$ & $171 \pm 1^{\mathrm{ab}}$ & $420 \pm 9^{\mathrm{a}}$ & $2.46 \pm 0.06^{\mathrm{a}}$ \\
CA 20\% & $29.2 \pm 0.7^{\mathrm{a}}$ & $171 \pm 1^{\mathrm{ab}}$ & $518 \pm 20^{\mathrm{b}}$ & $3.0 \pm 0.1^{\mathrm{b}}$ \\
CA 50\% & $30 \pm 1^{\mathrm{a}}$ & $168 \pm 2^{\mathrm{a}}$ & $518 \pm 32^{\mathrm{b}}$ & $3.1 \pm 0.2^{\mathrm{b}}$ \\
CI 20\% & $29 \pm 1^{\mathrm{a}}$ & $172.3 \pm 0.8^{\mathrm{b}}$ & $477 \pm 25^{\mathrm{ab}}$ & $2.8 \pm 0.1^{\mathrm{ab}}$ \\
CI 50\% & $29 \pm 1^{\mathrm{a}}$ & $169.9 \pm 0.1^{\mathrm{ab}}$ & $487 \pm 20^{\mathrm{ab}}$ & $2.9 \pm 0.1^{\mathrm{ab}}$ \\
\hline
\end{tabular}

Data corresponds to mean values and standard deviations of three samples.

Values with different letters in each column are significantly different $(p<0.05)$.

This article is protected by copyright. All rights reserved 
Table 3. Parameters obtained from texture profile analysis of breads.

\begin{tabular}{c|llll}
\hline \multirow{2}{*}{ Fortification } & \multicolumn{4}{|c}{ Texture Profile Analysis } \\
\cline { 2 - 5 } & $\begin{array}{c}\text { Hardness } \\
\text { (N) }\end{array}$ & Cohesiveness & Springiness (cm) & Chewiness (N*cm) \\
\hline Control & $10 \pm 2^{\mathrm{a}}$ & $0.708 \pm 0.009^{\mathrm{a}}$ & $1.17 \pm 0.06^{\mathrm{a}}$ & $8 \pm 2^{\mathrm{ab}}$ \\
LA 20\% & $17 \pm 2^{\mathrm{b}}$ & $0.65 \pm 0.02^{\mathrm{a}}$ & $1.16 \pm 0.05^{\mathrm{a}}$ & $12 \pm 2^{\mathrm{abc}}$ \\
LA 50\% & $18 \pm 1^{\mathrm{b}}$ & $0.67 \pm 0.01^{\mathrm{a}}$ & $1.097 \pm 0.002^{\mathrm{a}}$ & $13.0 \pm 0.7^{\mathrm{c}}$ \\
CA 20\% & $10 \pm 3^{\mathrm{a}}$ & $0.70 \pm 0.03^{\mathrm{a}}$ & $1.24 \pm 0.04^{\mathrm{a}}$ & $9 \pm 2^{\mathrm{ab}}$ \\
CA 50\% & $8.9 \pm 0.2^{\mathrm{a}}$ & $0.72 \pm 0.01^{\mathrm{a}}$ & $1.20 \pm 0.01^{\mathrm{a}}$ & $7.7 \pm 0.3^{\mathrm{a}}$ \\
CI 20\% & $14 \pm 2^{\mathrm{ab}}$ & $0.67 \pm 0.02^{\mathrm{a}}$ & $1.20 \pm 0.02^{\mathrm{a}}$ & $12 \pm 1^{\mathrm{abc}}$ \\
CI 50\% & $13 \pm 3^{\mathrm{ab}}$ & $0.690 \pm 0.08^{\mathrm{a}}$ & $1.2 \pm 0.1^{\mathrm{a}}$ & $11 \pm 3^{\mathrm{abc}}$ \\
\hline
\end{tabular}

Data corresponds to mean values and standard deviations of three samples.

Values with different letters in each column are significantly different $(p<0.05)$.

This article is protected by copyright. All rights reserved 
Table 4. Colour parameters of the crust and relative frequencies of hole diameters of the crumb.

\begin{tabular}{|c|c|c|c|c|c|c|c|}
\hline \multirow{2}{*}{ Fortification } & \multicolumn{4}{|c|}{ Crust } & \multicolumn{3}{|c|}{$\begin{array}{c}\text { Hole diameter } \\
\text { (relative frequencies of intervals) }\end{array}$} \\
\hline & $L^{*}$ & $a^{*}$ & $b^{*}$ & $\mathrm{BI}$ & $\begin{array}{c}0.0-0.1 \\
(\mathrm{~cm})\end{array}$ & $\begin{array}{c}0.1-0.2 \\
(\mathrm{~cm})\end{array}$ & $\begin{array}{c}0.2-0.3 \\
(\mathrm{~cm})\end{array}$ \\
\hline Control & $53.8 \pm 0.6^{b c}$ & $12.7 \pm 0.4^{\mathrm{bc}}$ & $37 \pm 2^{b}$ & $121 \pm 9^{b}$ & $84 \pm 3^{a}$ & $14 \pm 2^{a}$ & $2 \pm 1^{a}$ \\
\hline LA $20 \%$ & $52.4 \pm 0.7^{\mathrm{ab}}$ & $13 \pm 1^{c}$ & $37 \pm 2^{b}$ & $127 \pm 14^{b}$ & $83 \pm 1^{a}$ & $14 \pm 1^{a}$ & $3 \pm 1^{a}$ \\
\hline LA $50 \%$ & $50 \pm 1^{a}$ & $13 \pm 1^{b c}$ & $35 \pm 3^{b}$ & $133 \pm 23^{b}$ & $88 \pm 2^{a}$ & $11 \pm 1^{a}$ & $1.0 \pm 0.8^{a}$ \\
\hline CA $20 \%$ & $54.9 \pm 0.6^{\mathrm{bcd}}$ & $11 \pm 1^{a b}$ & $33 \pm 4^{\mathrm{ab}}$ & $103 \pm 16^{\mathrm{ab}}$ & $84 \pm 2^{a}$ & $15 \pm 3^{a}$ & $1.0 \pm 0.3^{a}$ \\
\hline CA $50 \%$ & $54 \pm 2^{b c}$ & $13.1 \pm 0.4^{b c}$ & $39 \pm 2^{b}$ & $133 \pm 5^{b}$ & $85 \pm 3^{a}$ & $13 \pm 1^{a}$ & $2 \pm 2^{a}$ \\
\hline $\mathrm{Cl} 20 \%$ & $56.4 \pm 0.3^{\mathrm{cd}}$ & $11.1 \pm 0.5^{b}$ & $33 \pm 3^{a b}$ & $98 \pm 10^{\mathrm{ab}}$ & $87 \pm 2^{a}$ & $11 \pm 2^{\mathrm{a}}$ & $2.0 \pm 0.4^{a}$ \\
\hline Cl $50 \%$ & $57 \pm 1^{d}$ & $8.8 \pm 0.8^{a}$ & $25 \pm 5^{a}$ & $69 \pm 15^{a}$ & $82.5 \pm 0.8^{a}$ & $15.5 \pm 0.9^{a}$ & $2.0 \pm 0.3^{a}$ \\
\hline
\end{tabular}

Data corresponds to mean values and standard deviations of three samples.

Values with different letters in each column are significantly different $(p<0.05)$.

This article is protected by copyright. All rights reserved 
Table 5. Calcium content on digest and dialysate, and potential calcium contribution (PCaC) of breads.

\begin{tabular}{cccc}
\hline Fortification & $\begin{array}{r}\text { Digest } \\
\text { (mg of } \\
\text { Ca/portion } \\
\text { of 200 g) }\end{array}$ & $\begin{array}{r}\text { Dialysate } \\
\text { (mg of } \\
\text { Ca/portion } \\
\text { of 200 g) }\end{array}$ & $\begin{array}{c}\text { PCaC } \\
\text { (mg of } \\
\text { Ca/portion } \\
\text { of 200 g) }\end{array}$ \\
\hline Control & $65 \pm 3^{\mathrm{a}}$ & $34 \pm 6^{\mathrm{a}}$ & $33 \pm 8^{\mathrm{a}}$ \\
LA 20\% & $269 \pm 20^{\mathrm{b}}$ & $92 \pm 6^{\mathrm{b}}$ & $68 \pm 9^{\mathrm{ab}}$ \\
LA 50\% & $519 \pm 68^{\mathrm{c}}$ & $195 \pm 19^{\mathrm{c}}$ & $196 \pm 28^{\mathrm{d}}$ \\
CA 20\% & $256 \pm 6^{\mathrm{b}}$ & $81 \pm 11^{\mathrm{b}}$ & $74 \pm 8^{\mathrm{ab}}$ \\
CA 50\% & $551 \pm 29^{\mathrm{c}}$ & $140 \pm 17^{\mathrm{c}}$ & $116 \pm 5^{\mathrm{c}}$ \\
Cl 20\% & $222 \pm 31^{\mathrm{b}}$ & $91 \pm 3^{\mathrm{b}}$ & $91 \pm 16^{\mathrm{b}}$ \\
CI 50\% & $498 \pm 64^{\mathrm{c}}$ & $194 \pm 16^{\mathrm{c}}$ & $196 \pm 34^{\mathrm{d}}$ \\
\hline
\end{tabular}

Data corresponds to mean values and standard deviations of three samples.

Values with different letters in each column are significantly different $(p<0.05)$.

This article is protected by copyright. All rights reserved 


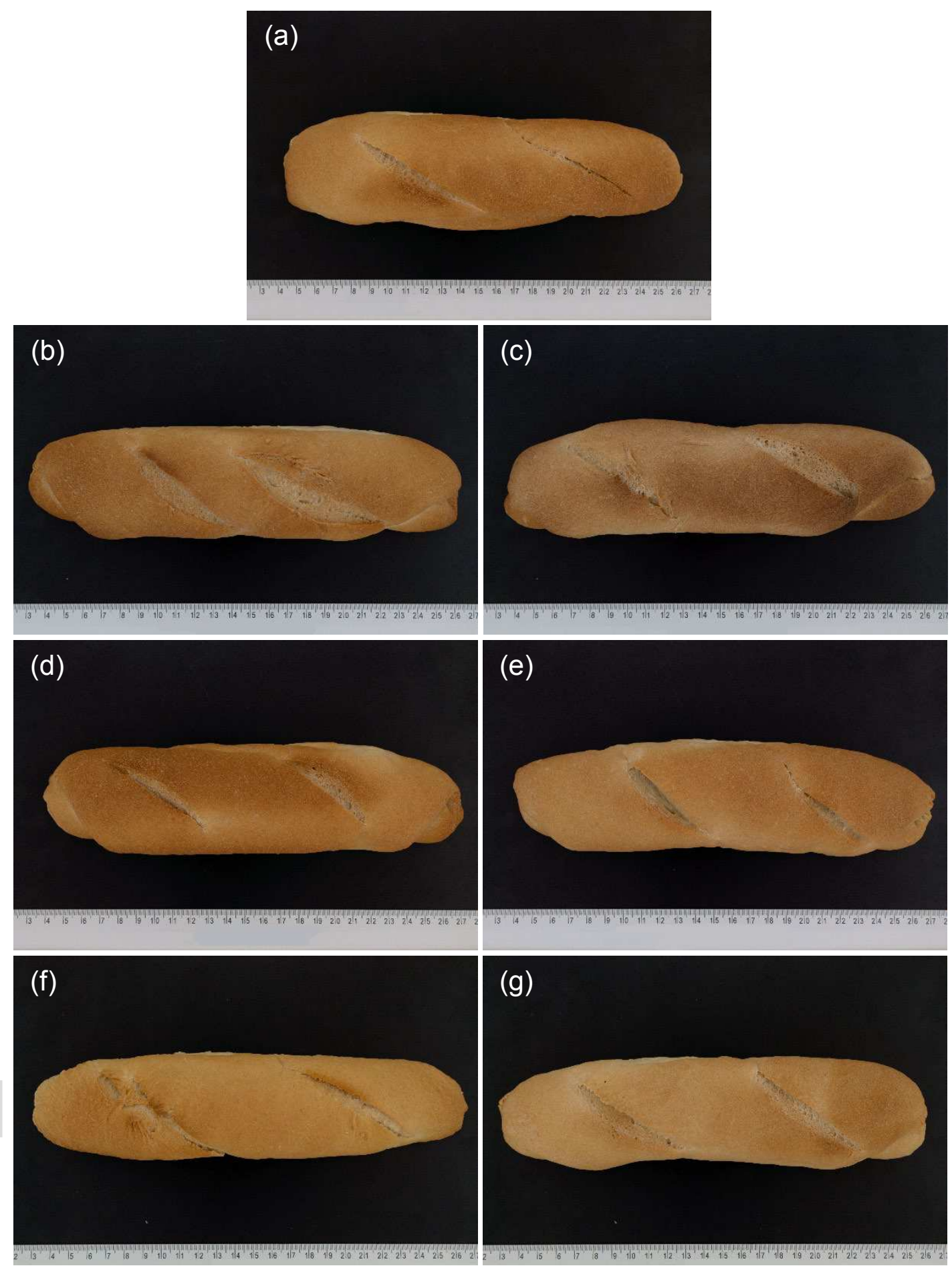

This article is protected by copyright. All rights reserved 


\section{Figure 2}

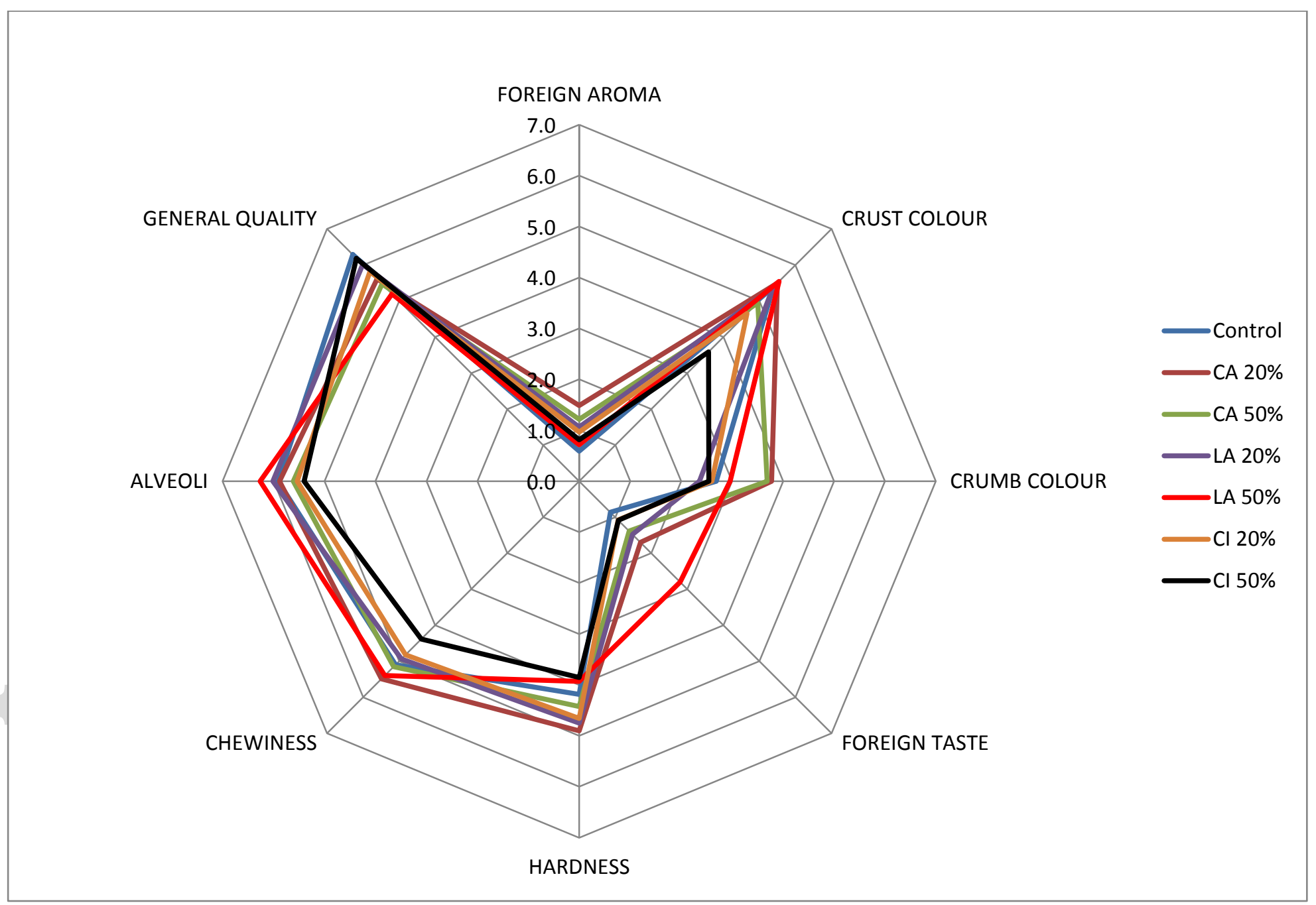

Colour for online version

This article is protected by copyright. All rights reserved 


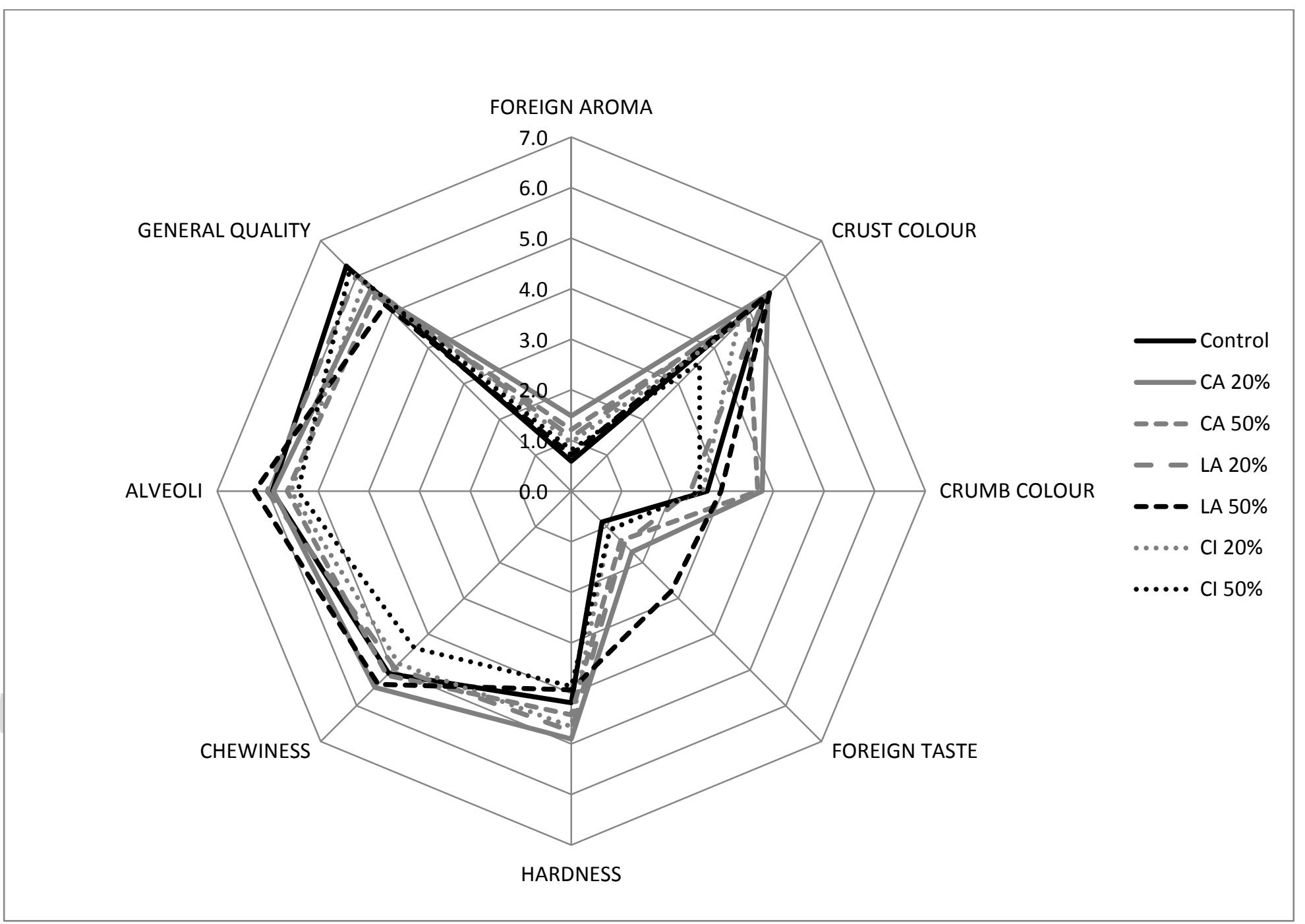

Black and white for printed version

This article is protected by copyright. All rights reserved 